\title{
STRATEGIES FOR TOURISM DEVELOPMENT IN NATIONAL PARKS WITH THE USE OF SWOT MODEL (CASE: GOLESTAN NATIONAL PARK)
}

\author{
Khodarahm Bazzi ${ }^{1}$--- Gholam Reza Khoshfar ${ }^{2}$--- Hossein Mousa Zadeh ${ }^{3} \uparrow$ \\ 'Associate Professor, department of geography and urban planning, Golestan University, Gorgan, Iran \\ `Assistant Professor, Department of political and social science, Golestan University, Gorgan, Iran \\ ${ }^{s}$ M.A. Student of Geography and Urban Planning, Golestan University, Gorgan, Iran
}

\begin{abstract}
Nowadays, tourism industry is one of the important sources of production, income, occupation and building infrastructure to achieve sustainable development. In addition many of the policy makers and development planners reminded it as a main pillar of sustainability. According to this, tourism in national parks is considered as an important dimension of tourism. Due to this, there is a question here which is what are the potentials and tourism limitations in national parks? And how can we use the strategies to improving the tourism development in national parks which causing the tourism growth and also the national development? According to this, the present article by using the field studies, determining the strength and weaknesses, opportunities and threats is offering strategies and solutions in order to tourism development in Golestan National park. The achieved results of SWOT method showed that the mentioned area has vast capabilities in tourism which requiring attention and appropriate planning in this area.
\end{abstract}

Keywords: Tourism development, SWOT model, Strategies, Strength and weaknesses, Opportunities and threats, Golestan national park.

Received: 22 October 2014/ Revised: 26 November 2014/ Accepted: 29 November 2014/ Published: 3 November 2014

\section{Contribution/ Originality}

Due to the importance of the role of Golestan National Park in attracting tourists and the lack of the sufficient attention to this issue, we can say this present article is to identify the capabilities and existence potentials in the region; and indeed, the main role of this article is to provide solutions to develop tourism in Golestan National Park. 


\section{INTRODUCTION}

Tourism industry develops these days in the world. Many countries can improve their status and decrease their unemployment, income per capita and depreciation of the exchange income. Tourism industry is big art in the world, for many countries this dynamic art is essential source income, employment, private sector and substrata development. Nowadays tourism exists in new interplay in human being (Boniface and Fowler, 1993).

Tourism in these world ties to economic financial, as we can say tourism after three dimension (industry, agronomy and services) can be the fourth dimension in all of the countries. International tourism organization express, tourist consists of activities that tourists do (WTO, 1996).

This smokeless industry has valuable rule of identifying some zones. Development of national parks with past method don't respondent nowadays because of soma problem like poverty, hygiene, employment and safety alimentary. Planners and politic mans should fallow some new strategy and method for development of national parks. One of the best work that other country doing is tourist development in national parks that have ability to attract the tourist.

According to this subject for survey tourism development in national park specials in our study, because of its structural, places, ecology have specific station for pass leisure time is special for travelers through occurred in Mashhad international pathway necessity use of this new strategy and method feel in the jungle, mountains area special in ecologically situation.

In this article and according to subject, identify ability and potential in study area and aware of problem and lack of surrounding Golestan national park can have effect on suitable planning in this area, trying to identify and introduce ability for survey their strength, weaknesses, opportunities, and threats point from their specialist an at the end according to their opinion, method, standard point optimum from their opportunities and support or obviation, their weaknesses and threat for access to tourism development in national park.

\subsection{Definition and Contexts Theoretical}

Recently tourism industry is effective in creation employment and zonal development, and an element to create motivation in public economy. Industry development in the developed country cause variety income and decrease inconsistency and in the developing country causes opportunity to export, exchange production and employment. Therefore, it is need to accompany by increasing tourists in order to make optimum tools, (Mekaeeli, 2000) and also it is necessary to identify attractive in the first stage and planning to development in the next stage, (Behzadfar and Zamanian, 1989). Yet supervision on tourism law is necessary. so we should try to management notice ability, and correct plan for extension tourism, (Mahallati, 2001). national park is confine of natural resources consist of jungle, posture, forest, desert, river, lake and mountain , that show sample of masterwork in our beautiful nature government protect this area because of their preservation existence situation, create an appropriate environment for reproduction wide animals ,growth, risk extinction plants and protection from human interference, (Rowman and 
Littlefield, 1997). United States America is the first country that starts nature protection policy and established national park. National park systems is the best American idea, (Florian, 2008). One of the important tools in guideline process is SWOT is tool guideline planning, (Hom Haacke, 2001) and is a definition frame for system analysis, (Nourei et al., 2006). Nowadays SWOT as a modern tools used to analysis performance and gap situation by designer and evaluators, (Nilsson, 2004). Designer can use internal matrix evaluation to identify related between different topics then give them appropriate situation, (David, 2004). This matrix can provide four choice from different responses degree, of course in process some guideline operate in the same time, (Harrison and Jon, 2003).

\section{RESEARCH METHODS}

To achieve the research goals in this article, first the mixed, descriptive and analytical methods are used. According to the present information, this section is focused on checking attractions, facilities, services, tourism status and its effects in society development. And then in other steps of the research for analyzing and providing strategies and appropriate developing solutions of tourism the SWOT method is used. At First, the effective factors on internal and external environment of the region, the list of strength and weakness points, opportunities and the threats are recognized, and then by feedback from the people, tourists and the relevant authorities and valuing each of these issues and then calculation and analyzing, the priorities are identified, and finally in order to decreasing or removing the threats and the region weak points, spreading and reinforcing the strengths and opportunities related to planning and tourism development in the studied area, suggestions and appropriate strategies are provided.

\subsection{Golestan National Park Introduction}

Golestan national park is the first national park in Iran. This was identifying as huntingground and called Golestan jangle park before1957. In August 1957changed its name to protection area Almeh and Ishki that hunting club supported it, until 1961could show its ability because of their control and support. In February 1961 without any change in its extent called Alamo protection area. In August 1963had changed its name to Mohammad reza king park and after one year again changed its name to Mohammad reza king wild park .since established hunting and control of hunting organization in 1967, duty of hunting camp and control of wild park conceded to this organization. In August 1971, a part of the east Gharkhod protection area with extent of 34000 hectare joined to the park. After change name of the wild park to the national park in law hunting adjustment at 1974, its name changed to national park. At 1976 both protect area contraction together and make one area that called national park extension with 125895 hectare. After revolution at 1978 Gharkhod protection area separated from national park till now.

Golestan national park has protected extension with 91895 hectare and at 1997, chooses as settlement cache and the earth plan project number8 by UNESCO, and until now protect its place as world settlement cache. Golestan national park is the only park protects its occasion as national park in the recent decades. 


\subsection{Some Feature of Golestan National Park}

Golestan national park have unique feature that make it different from other park, referred it flow:

1-Golestan national park is the oldest protection area, its history and background return to 4 decade. The history of protect this area express its importance in network protection area additionally to more than $50 \%$ of protection area in the world established after 1982, so we can say it is the oldest national park in the world.

2-eightth species plants, third of species birds and more than $50 \%$ of species mammals in Iran live in the national park.

3- Existence of special animals, this settlement for wild sheep, Ariel, which is the biggest and oldest sheep species that equal of three quarter of total population of world sheep. And of course jungle sable is zoophagous which may live only in Golestan national park and increase the genetic value.

4-existenceof special plants a kind of crocus is in the national parks that don't find anywhere.

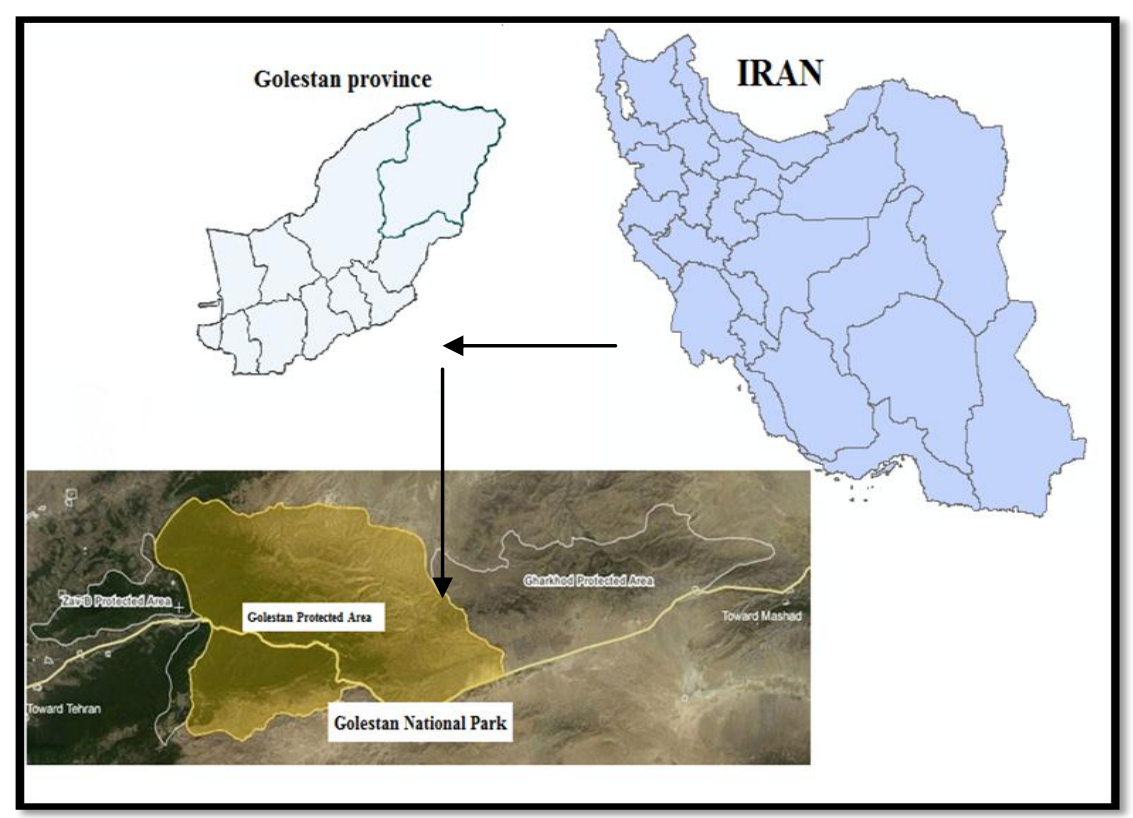

The position of a Golestan national park on the map

\subsection{Vegetation}

Different species exists in the park like fern grow in down of the park, in driest area is shrubs, barberry, tagh, manna-tree, kollahmir Hassan bush ,goats, ford, a kind of soupy root, worm seed (santinica), camels-thorn shrubs and in the high area we could see arrases species.

\subsection{Wild Life}

There is 69 species mammal related to 6 rows, 21 families, 50 geniuses identify in Golestan national park. Tiger and brown bear is the big zoophagous in the national park sable is one of the 
zoophagous that increase genetic value of the park. This area is the best settlement of wild sheep (Oriel) in Iran and has one of the purest populations of sheep.

\section{ANALYSIS OF DISCOVERY}

In order to show strategy of tourism development in Golestan national park use of SWOT and shoe strength and weaknesses, opportunity and threats are necessary. Analyses SWOT for identify effective internal elements (strength and weaknesses) and effective external elements (opportunities and threats) use to show tourism development strategy. For realization of this topic at first we should identify strength, weaknesses, opportunities and threats and then asking from local management and expert and emphasize to all of them then its calculation and analysis for characterize preference and remove and decrease weaknesses and threats and improvement strength and opportunity special tourism development adaptable strategy.

\subsection{Effective Internal Elements in Tourism Development}

The purpose of this process is research the internal factors tourism development in that area for identify the internal elements (strength and weaknesses) according to study and survey environment situation evaluate all effective elements.

Table-1. Strengths

\begin{tabular}{|c|c|c|c|c|}
\hline Row & Strengths & $\begin{array}{c}\text { Total } \\
\text { scores }\end{array}$ & $\begin{array}{l}\text { average } \\
\text { scale }\end{array}$ & rank \\
\hline 1 & Existence of Golestan water fall and beautiful promenade & 809 & $4 / 04$ & 1 \\
\hline 2 & $\begin{array}{l}\text { there are unique and beautiful natures with many social } \\
\text { places in village zone }\end{array}$ & 722 & $3 / 61$ & 2 \\
\hline 3 & $\begin{array}{l}\text { Existence of suitable network relate (settling in Mashhad } \\
\text { line) to easily access of tourists. }\end{array}$ & 715 & $3 / 57$ & 3 \\
\hline 4 & $\begin{array}{l}\text { Able to this area as investment and tourism planning for } \\
\text { use of nature resource and introducing as the tourism pole } \\
\text { in Golestan. }\end{array}$ & 696 & $3 / 48$ & 4 \\
\hline 5 & $\begin{array}{l}\text { Have quite place and without noise, special for tourist rest } \\
\text { and play }\end{array}$ & 670 & $3 / 35$ & 5 \\
\hline 6 & $\begin{array}{l}\text { Existence of some unique feature like, special plants and } \\
\text { animals in this area. }\end{array}$ & 660 & $3 / 30$ & 6 \\
\hline 7 & $\begin{array}{l}\text { Opinion of management is about employment work for } \\
\text { village development. }\end{array}$ & 641 & $3 / 20$ & 7 \\
\hline 8 & People high motivation for create and develop of tourist. & 595 & $2 / 97$ & 8 \\
\hline 9 & $\begin{array}{l}\text { Existence of appropriate structural for walking, rock } \\
\text { walking and mountain eely. }\end{array}$ & 568 & $2 / 84$ & 9 \\
\hline 10 & $\begin{array}{l}\text { Existence of some culture and tradition that are remain } \\
\text { from past. }\end{array}$ & 505 & $2 / 52$ & 10 \\
\hline
\end{tabular}

Source: research findings 
Table-2. Weaknesses

\begin{tabular}{l|l|l|l|l}
\hline Row & Weaknesses & $\begin{array}{l}\text { Total } \\
\text { scores }\end{array}$ & $\begin{array}{l}\text { average } \\
\text { scale }\end{array}$ & rank \\
\hline 1 & $\begin{array}{l}\text { Ignore to the national park as the big national park in } \\
\text { Iran and inattention to settlement cache. }\end{array}$ & 720 & $3 / 61$ & 1 \\
\hline 2 & $\begin{array}{l}\text { Weaknesses of planning and management and } \\
\text { government investments in this area. }\end{array}$ & 695 & $3 / 47$ & 2 \\
\hline 3 & $\begin{array}{l}\text { Tendency of people to use specially environment of } \\
\text { village. }\end{array}$ & 682 & $3 / 41$ & 3 \\
\hline 4 & $\begin{array}{l}\text { Have possibility of flood occurrence. } \\
\text { Cultural differences between rural people and } \\
\text { tourists. }\end{array}$ & 6347 & $3 / 23$ & 4 \\
\hline 5 & $\begin{array}{l}\text { Unsuitable distribution tourist in deferent season. } \\
\text { less compression in winter) }\end{array}$ & 617 & $3 / 08$ & 6 \\
\hline 6 & $\begin{array}{l}\text { lack of existence of specialist in this area } \\
\text { Have unsuitable convenience residence and hygienic. }\end{array}$ & 614 & $3 / 07$ & $2 / 80$ \\
\hline 8 & $\begin{array}{l}\text { lack of teaching and identifying villagers for relate to } \\
\text { tourism }\end{array}$ & 546 & $2 / 73$ & 8 \\
\hline 9
\end{tabular}

Source: research findings

\subsection{Effective External Elements in Tourism Development}

The purpose of this process is evaluation external effective element in the area, in order to identify threat and opportunity. It means some point that helps us to access to purpose is our considered.

Table-3. Opportunities

\begin{tabular}{|c|c|c|c|c|}
\hline Row & Opportunities & $\begin{array}{l}\text { Total } \\
\text { scores }\end{array}$ & $\begin{array}{l}\text { average } \\
\text { scale }\end{array}$ & rank \\
\hline 1 & $\begin{array}{l}\text { Cross many travelers and residence in promenade } \\
\text { national park. }\end{array}$ & 715 & $3 / 57$ & 1 \\
\hline 2 & $\begin{array}{l}\text { Use of cultural thing with attractive nature increasing } \\
\text { tourist's travel and play in this area. }\end{array}$ & 700 & $3 / 50$ & 2 \\
\hline 3 & $\begin{array}{l}\text { Create a chance to sell of their handicraft production } \\
\text { increase their income. }\end{array}$ & 674 & $3 / 37$ & 3 \\
\hline 4 & $\begin{array}{l}\text { A production chance from environment and species } \\
\text { plants and animals. }\end{array}$ & 663 & $3 / 31$ & 4 \\
\hline 5 & $\begin{array}{l}\text { There are some organizations for give services to } \\
\text { villager. }\end{array}$ & 660 & $3 / 30$ & 5 \\
\hline 6 & $\begin{array}{l}\text { Protective law and regulations of industry and there are } \\
\text { special credit line for the development of ecotourism. }\end{array}$ & 646 & $3 / 23$ & 6 \\
\hline 7 & $\begin{array}{l}\text { Increase attention and motivation of government and } \\
\text { the private sector to invest an area. }\end{array}$ & 645 & $3 / 22$ & 7 \\
\hline 8 & Prevent rural migration. & 644 & $3 / 22$ & 8 \\
\hline 9 & $\begin{array}{l}\text { Increased attention and support national authorities in } \\
\text { charge of rural development approach to job creation. }\end{array}$ & 630 & $3 / 15$ & 9 \\
\hline 10 & $\begin{array}{l}\text { Creating employment opportunities feeling among } \\
\text { residents especially woman and youth. }\end{array}$ & 578 & $2 / 89$ & 10 \\
\hline
\end{tabular}

Source: research findings 
Table-4. threats

\begin{tabular}{l|l|l|l|c}
\hline Row & Threats & $\begin{array}{l}\text { Total } \\
\text { scores }\end{array}$ & $\begin{array}{l}\text { average } \\
\text { scale }\end{array}$ & rank \\
\hline 1 & $\begin{array}{l}\text { Land erosion because of excavation from riverbed and } \\
\text { rising to inundations area. }\end{array}$ & 733 & $3 / 66$ & 1 \\
\hline 2 & Introduction line and build wall between lines. & 715 & $3 / 57$ & 2 \\
\hline 3 & $\begin{array}{l}\text { Change the farm lands by exchanger in the environs } \\
\text { study area. }\end{array}$ & 713 & $3 / 56$ & 3 \\
\hline 4 & Lack of specialist to guide investors in ecotourism part. & 685 & $3 / 42$ & 4 \\
\hline 5 & $\begin{array}{l}\text { Destroyed the vegetation and increased air, water, noise } \\
\text { pollution in this area. }\end{array}$ & 665 & $3 / 32$ & 5 \\
\hline 6 & $\begin{array}{l}\text { Increased recreational facilities and services in area such } \\
\text { as the cities of rivals. }\end{array}$ & 642 & $3 / 21$ & 6 \\
\hline 7 & $\begin{array}{l}\text { Not issued by the government to expand the facility to } \\
\text { meet national park ecotourism. }\end{array}$ & 622 & $3 / 11$ & 7 \\
\hline 8 & $\begin{array}{l}\text { People low motivation in other cities to invest in this } \\
\text { area due to investment in successful regions. }\end{array}$ & 598 & $2 / 99$ & 8 \\
\hline 9 & Destroyed farm lands. & 527 & $2 / 63$ & 9 \\
\hline
\end{tabular}

Source: research findings

\section{ANALYSIS, SURVEY AND PRIORITIZATION OF STRENGTH, WEAKNESSES, OPPORTUNITIES AND THREATS}

According to result of matrix in before lists, express that , existence of Golestan waterfall ,museum, and other attractive places like beautiful promenade and ... the total score 809 and the average scale 4/04 is the important strength point, and after that existence of beautiful and unique nature with total score 722 and average scale 3/61 is in the next level, also existence manners local culture and traditional and interesting for us from past with total score 505 and average scale $2 / 52$, and appropriate infrastructure exist in rock walking, mountaineering and walking the total score is 568 and average scale $2 / 84$, is respective import lees in the strength.

In the survey the weaknesses ignore to the Golestan national park as the biggest national park in Iran and inattention to cache settlement the total score720 and average sale 3/60, and infirmity of planning, management and government investment in this area with total score 695 and average scale $3 / 47$ is the important weaknesses .also lack of cognition villager and lack of instruction in relate to tourists with total score 646 and average scale $2 / 80$, and existence of inappropriate residence, material and hygiene with total score 561 and average scale $2 / 80$ is the import less weaknesses.

About opportunity management believed that cross of the tourists and residence in the promenade in the national park with total score715 and average scale 3/57 is the first preference and then use of culture with natural attractive in order to increasing tourists travel in this area the total score is 700 and average scale $3 / 50$ is in the next stage. Also create occasion work and employment between woman and youth with total score 578 and average scale 2/86 and also support and attention of government for village development with the purpose of creating income is the import less opportunity. 
Also land erosions because of excavation from riverbed and giving rise to inundation area with total score 733 and the average scale 3/66 is the important threat, introduction line and build wall between line and river with total score 715 and the average scale $3 / 57$ is in the next position. And also destroyed farm lands with total score 527 and average scale $2 / 63$ and people low motivation for investments in this area because of their investments in successful area the total score is 568 and the average scale is $2 / 60$ are the import less threats in this area.

\subsection{Strategy Presentation for Development Golestan National Park of Ecotourism by SWOT Analyzing Method}

\subsubsection{Competitive Strategy (SO)}

In competitive strategy the focus is on the internal strengths and external opportunities, in this situation the area should try for its development by strength (Golkar, 2005), in the flow refer to ecotourism development.

1- Trying to identify and using of natural and ecotourism attractive to attack people and competition with other tourist zone.

2- Beneficial using of increasing travelers motivation between urban people as using nature and create employment and income between rural people.

3- Emphasis on natural tourism development because of existence potential in the study area.

4- Using of supporting private sector to investment in ecotourism in the study area.

5- Using of governments as tourism industry development to create new work and income for peoples of this area.

6- Use of some specialist's person as create cooperation and teaching from meeting to people and using of native investor.

7- Create harmony between companies in order join rural tourism operation by meeting and use of appropriate management measure.

\subsection{Variety Strategy (ST)}

-In the variety of strategy emphasis is on the internal strength and external threat, in flow sentences refer to decrease threat and use the supremacy in ecotourism development in the rural area.

1- Strategic planning to give variety services, residence, play and hygienic as satisfy tourists and then, increasing tourism and employment for people who live in this area.

2- Create law and some services for avoid from destroyed vegetation and land erosion because of excavation from riverbed and danger of flood.

3- Create variety and developments of commercial plans for introduce national park and attractive nature by carnivals and seminars.

4- Planning and organizing agronomy tourism as using of beautiful environment and avoid from farm destroying and beautiful nature.

5- Local management trying for organization and avoid of farm destroying.

6- Development and outfit of ecotourism path and create some guide book for tourists. 
7- Social security place and tourist village around national park to avoid of social violation.

\subsection{Style Weekly (WO)}

In this method addition to emphasis internal weaknesses, trying to use external opportunity for removal weaknesses in this area, so in the flow suggested some way for use of opportunity and removal weaknesses in ecotourism development.

1- Control to how prevalence of equipment to this area.

2-Planning to use the private company and communion people to attract tourism for prevalence of services, hygienic and residence.

3-Control farm law in ecotourism places to use of all parts for all people.

4-Development Company for teaching people and tourists as using positive effect and sources of ecotourism.

5- Controlling to type of prevalence and preference of asset and trying to attract investments for rural development.

\subsection{Defensive Strategy (WT)}

The defensive strategy is basis on the internal weaknesses and external threat, the flow topics suggest to removal damaged and weaknesses and threats for ecotourism development.

1-Teaching crisis management to native people for increasing safety according to natural vulnerable and possibility of occurrence of unpredicted event like flood, earth quick, downfall...

2-Create special law in order to beneficial using of natural attractive and avoid of farm, jangle, soil, air, water pollution damaged.

3- Holding seminars to investment in order to industry development of rural tourism by their management, invite internal and external investors, create special score for investment in build hotels, sport fields, recreational facilities, nature history museum and rural landscapes.

4-Teaching and information to people in relate to tourists, for avoid them from delinquency and crime, conflicts regional tourism in terms of formality.

5- Facilities outfit and medical services with their specialists.

6 - Encouragement people to involve in development of facilities, outfits and income from ecotourism and also using private sector when people can't involve inn some fields.

7- Use of some specialist for development of ecotourism by supporting from government.

\subsection{Planning, Presidency and Evaluating}

-This is last process of strategic planning for ecotourism development in the area, and consists of planning and politics of ecotourism development and pattern preparation of action planning. In this method of planning editing mode to adjust of final and purpose, in addition presidency an evaluating mechanism present by this politics.

According to ecotourism development we can present in short and long time planning in this area. 


\subsection{Long Term Planning}

1- Rest ruction development at a same time in tourism industry, national parks development as achieve their goal, sustainable development and economic growth.

2-Create bazaar for long or short time because tourists like handicrafts and it is good income for rural to increasing their income.

3- Congress to hold or develop ecotourism by ecotourism society in order to promote ecotourism like orientation of new idea and theories, familiar with the developed and developing countries experience in field of ecotourism.

4-Setting up local hotel and rural management can take effective steps, use of old and attractive places for tourist staying, and preparing appropriate programs like local music and dance.

5-The optimal model for ecotourism development, preparing appropriate program and ecological conditions and minimizes the damaging effect of the environment.

6- Improvement of infrastructure development that consist of developing communication network and information technology in the study area.

\subsection{Short Term Programs}

1- Modify rules for the development of ecotourism by the relevant.

2- Establishing tourism offices in village that create job and guide tourists.

3- Cultural practices and beautify parks.

4- Support relevant organization to attract tourist with appropriate plans like health, services, accommodation.

5- Management organization in order to implementation of government decision.

Funding: This study received no specific financial support.

Competing Interests: The authors declare that they have no competing interests.

Contributors/Acknowledgement: All authors contributed equally to the conception and design of the study.

\section{REFERENCES}

Behzadfar, M. and R. Zamanian, 1989. Application of multi criteria decision making AHP in tourism planning, case NEYSHABUR city. International Journal of Engineering, 18(5).

Boniface, P. and P.J. Fowler, 1993. Heritage and tourism in the 'global village. London: Routledge. pp: 175.

David, F.R., 2004. Strategic management, translated by Mohammad Ali Parsaeian and Mohammad Arab. 11 th Edn., Tehran: Publications Office of Cultural Research Iran.

Florian, S., 2008. Yellowstone To Yukon freedom to roam. Australia: Published by Mountaineers Books.

Golkar, K., 2005. On the occasion of Swot techniques for application in urban design. Tehran: Shahid Beheshti University, Saffeh Magazine, 15(41).

Harrison, J. and k. Jon, 2003. Strategic management, translated by B. Ghasemi. Tehran: Printing, Publications Board.

Hom Haacke, L., 2001. Using SWOT for project planning sessions, PN.3 hughes. A. Tourism as Sustainable Industry in the Rural Community of Arising, West Scotland, MSc Thesis, Napier University. 
Mahallati, S., 2001. Introduction to tourism. Tehran: Shahid Beheshti University.

Mekaeeli, A., 2000. Tourism planning based on ecological principles. Geographical Journal. Year 32(39).

Nilsson, M., 2004. Research and advice on strategic environmental assessment. Stockholm Environment in Statute Publications.

Nourei, J., M. Abbaspour and B. Maghsoudloukamali, 2006. Strategic environmental assessment policies of industrial development model using SWOT. Islamic Azad University,Tehran, Journal of Environmental Science and Technology, 8(29).

Rowman and Littlefield, 1997. The critical documents America's national park. U.S.A.: Published by Rowman \& Littlefield Publishers.

WTO, 1996. What tourism managers need to know. A practical guide to the development and use of indicators of sustainable tourism. Madrid: WTO. 